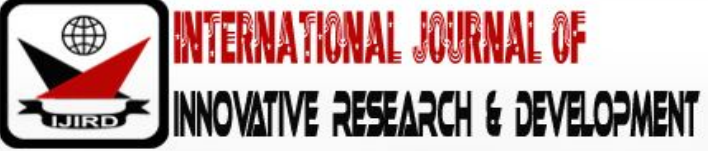

ISSN 2278 - 0211 (Online)

\section{Why the Geez Pharyngeal Sounds are Pronounced as the Glottal Sounds}

\author{
Zufan Gebrehiwet Hagos \\ Lecturer, Department of English language and Literature, Jigjiga University, Ethiopia
}

\begin{abstract}
:
Ge'ez is one of the most ancient languages in the world which was in use up to 10th centuries in Ethiopia. The writing system of Ge'ez is called Fidel, and the writing surface of it was Brana. Various studies had been conducted on Ge'ez phonetics. However, how to apply the symbols mainly the pharyngeal (in pronunciation) was not clearly put. These days the Ge'ez pharyngeal sounds are pronounced as glottal even though pharyngeals are attributes of the language. The purpose of this study is to investigate why Ge'ez pharyngeals are mispronounced. The research was designed based on the qualitative approach. Secondary data were collected from related materials and former phonetic researches. The data were analyzed qualitatively through narration. The Ge'ez pharyngeals [ $h: 0] /[\hbar, I]$ are transcribed as $/ \hbar / h /$ and $/ \mathcal{I} /$ in various phonetic researches, but these sounds are not still pronounced properly by the speakers. Thus, the researcher argued that the above symbols must be pronounced to their scientific nature since they are the actual transcriptions of the sounds. The researcher believes that the Ge'ez pharyngeals are pronounced as glottals due to the influence of Amharic Language. Most of the Times, the religious leaders learn Ge'ez in parts of Amhara region (Wollo, Gojjam, and Gonder) for Liturgy services these days. Amharic language has no pharyngeal sounds because of controversial influences.
\end{abstract}

Keywords: Pharyngealization, semeticness, influence, History, writing system

\section{Introduction}

\subsection{Ge'ez}

According to the Ethiopian Orthodox Tewahido, Ge'ez was the first language of the world. This shows as if all languages were derived from it relating with the context of the name "Adam". The name Adam in Ge'ez means 'beautiful creature' from that all people of the world are descended according to the creation point of View. So Ge'ez was the first language given to mankind and is not limited to the country (Ethiopia), as well as to the single Semitic language family. Nohamin (2008) states that "the word Ge'ez refers to 'The first' and its grammar was translated by Dilman (Germany

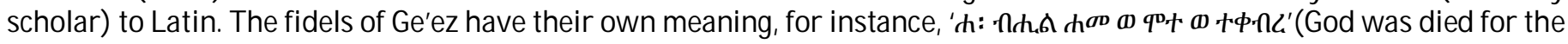
sake of the mankind)". The language was even in use during the first century at which Christianity was introduced to Ethiopia by Bacos the eunuch." Zera Dawit(2009), expresses that Bacos the eunuch learned Christianity in Jerusalem and

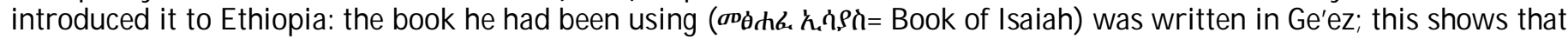
the language was in use in Ethiopia even before Christ un like the conclusion of some linguists and historians who argued as Ge'ez was in use in the country beginning from the 4 th century.

\subsection{Reviews on the Origin}

According the linguistics point of view, Ge'ez is one of the Afro Asiatic language families mainly of the Semitic branch used in Ethiopia beginning form the $4^{\text {th }}$ century, and later split to the daughter languages like Tigrigna, Amharic, and Tigre of Eritrea at the 10th century. Some of the scholars however concluded that Ge'ez was rather originated from the ancient Egyptian Hieroglyphics; Gabriella S (2001:6) exhibited sort of pictographs as some of the Ge'ez letters were developed from. Georges (1969) said that the Ge'ez system finds its origins purely in Egyptian Hieroglyphs, as does the well documented Roman system. And so would be theorized that Ge'ez syllographs fairly descended directly from Hieroglyphs. It is of note in this hypothesis, that the first and last syllographs of Ge'ez, Hä and Pä are relatively the same in Ancient Egypt as the first and last main Hieroglyphs. In addition, Gabrilla page 5, compared those symbols in her work. Baye (1992), however written that Ge'ez is no longer a spoken language these days; however, Ge'ez scripts have been serving the languages of many nationalities. The scripts do not belong to only one nationality. It has become the "feedel" of Ethiopia. In short, Ge'ez language died a long time ago after inheriting its "feedel" to Ethiopia. The language's birth place is Ethiopia and its nationality is Ethiopian. It does not exist in any other place. Therefore, it is one of our cultural treasures that make us distinct from other peoples (nations). As to him, the language was originated in Ethiopia. This idea opposes with the context of the Ethiopian Orthodox Tewahido which says Ge'ez was the first language of the world even used to 
name the mankind (Adam). Thus, Baye Yimam concluded that the language is limited only to Ethiopia, or this can lead us whether the first area where human being was created was Ethiopia.

Scholars argued that the script system of the language was originated from: Africa of Egyptian hieroglyphics writing system, the Southern Arabian Semitics, or Ethiopia of the proto Ethiopic (Sabaic). The script of Ge'ez through the system of Abugida is one of the oldest writing systems of the world according to Gabreilla. Ge'ez language historically used to create the Semitic languages of Ethiopia and some other Ethiopian Cushitic languages of horn Africa: Oromo, Somali, and Blin in Eretria. Ge'ez language's alphabets later split to the Semitic: Sebatibet, Tigrigna, Amharic of Ethiopian and Tigre and Tigrigna languages of Eritirea since the 13th century. According to Gabriella (1992), and Bekerie (1997), the Ge'ez system has five major properties: pictography, ideography, astrograph, numerology and Syllography. One of the main properties of Ge'ez is its pictography, meaning that the existing syllographs are derived from "images drawn or adapted from nature and the peoples' relation to it. Ideography, the second property of Ge'ez, means that the syllographs symbolize different ideas, value systems, and Philosophical and social orders. Astrograph, or the charting of the stars and hence, the calendar, is the third property of the Ge'ez system. The system with its 26 classes and 7 variations provide its total of 182 syllographs being half of 364, represents a half-year or one equinox. Each of the syllographs have a corresponding number value from 1-5600. The number values associated with each syllograph also contains codes of the Ethiopian knowledge (mystery) system. The numerical values assigned to syllographs and words in the Old Testament give insights into interpretation and provide memory markers for the oral retelling of the stories. For example, the name Abraham corresponds to the numeric value of $60(40+9+6+1+4)$.

\subsection{Pharyngeal Sounds}

Pharyngeal consonants are sounds articulated primarily in the pharynx. Some phoneticians distinguish upper phryngeals pronounced by retracting the root of the tongue in mid to upper pharynx. The pharyngeal sounds in IPA and Weninger (2010) are written as [ $\mathrm{\hbar}]$ voiceless pharyngeal fricative and $[\mathrm{I}]$ voiced pharyngeal fricatives. This research focused on the Ge'ez pharyngeals [ $\boldsymbol{h}]$ and $[0]$ and how they must be pronounced in the language. Baye (1986:13-15) in

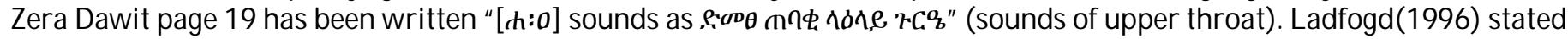
that pharyngeal sounds are known primarily in North Africa: mainly, in the Semitic language family. Related to this, Asher (1986) states that, "Pharyngeals are distinctive features in Semitic languages (Arabic, Geez, and Hebrew)".As stated above, Pharyngeal sounds are the main attributes of the Semitics including Ge'ez. Those sounds are among the Ge'ez fidels placed in the alphabetic order of the language even though they are currently pronounced as the glottals. It is highly predictable as the pharyngeal sounds of the language were pronounced formally in the past times. The related phonological system of other Semitic languages can give at least indirect hints for the historical pronunciation of certain phonemes. Additionally,

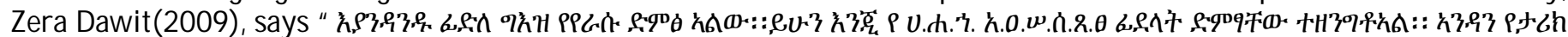

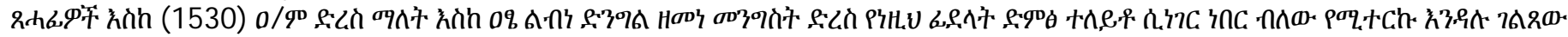
26.9А": : Nowadays however, the identity of the sounds is changed because of many controversial reasons. Even though many researches were conducted on Ge'ez phonetics, the reason why the pharyngeal sounds are not used or are used interchangeably with the glottal sounds is neither clearly known nor independently studied. Thus, the researcher was provoked to involve on how the pharyngeal sounds must be pronounced; studying the function of single symbol (letter) is a pivotal role in reconstructing and recognizing the language's own scriptural feature. On top of that, the number of the symbols will be reduced if the given sounds are mispronounced and not preserved. Speakers even may miss script the sounds/ fidäls depending on the auditory perspective of the sounds but different appearance and meaning. For example,

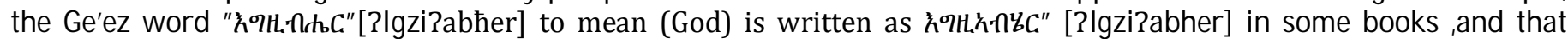
affects words to get different meaning or became meaningless as well as to decrease the number of the letters (fidäls). On top of that, Belay (2001) describes that, to replace one sound by the other leads phrases or words to have confused meaning or to lose their meaning at all. These symbols have to be, of course, understood by the users of the language.

\section{Methods}

This study focuses on how the Ge'ez pharyngeals are used these days. To carry out such diverse research requires defining the scope of the study there by creating concentration to the most basic discussion themes; otherwise, it might wind up with broad issues but less decisive annotations. For that reason, the researcher studied the sounding system of the pharyngeal sounds in the language using written materials by the sounds on which some words were constructed, and some other related researches conducted on the general phonetics of the language. The research was aimed at assessing: the effects of the faulty pronunciation of the sounds, the production point of the sounds, and their historical functions. The descriptive type of research through the qualitative designing was employed, and secondary data were deployed by using document analysis. Phonetic researchers related to the topic were purposely selected to have essential information regarding the data to make the analysis. Six materials (the works of Paolo Marassinni, Asher Lawfen and Thomas Baer, Wolf Leslau, Gabriella Scelta, Ladfoged Peter, and Stefan Weninger) were selected, and, linguistic transcription, and pronunciation of the pharyngeal sounds were observed. Thus, the researcher compared the sounds of the words constructed using both of the glottal and pharyngeal sounds with transcribed version of the words in the researchers; the way how the target sounds were transcribed was observed. The scholars transcribed the pharyngeal sounds $[\mathrm{h}]$ and $[0]$ as $[\mathrm{h} / \mathrm{h}]$ and $[\mathrm{C}]$, and the glottal sounds $[v]$ and $[\mathrm{h}]$ as [h] and [?] respectively. Ladfogd, and Gabriella however, transcribed them as [ $\hbar]$ and[C]. The researchers believed that the two ways of the transcriptions were valuable since the first is philological and the second is the IPA ways of transcription. The data were analyzed based on their historical, linguistic and pictographic functions. 


\subsection{Historical Analysis}

According to some linguists, the sounds (fidäls of Ge'ez) had been pronounced as to their natural appearance until the modern period. Among them were the target sounds [ $h]$ and $[0]$. Those sounds are phonetically sounded as $[\hbar]$ and[ $[\mathrm{C}]$ in Tigrigna, Tigre, and Me'en but not in Ge'ez currently. The symbols are the same in appearance in all the Ethio-semitic languages which were historically derived from Ge'ez, but the sounds nowadays became glottal in pronunciation both in Amharic and in Ge'ez. Some linguists and historians argued that it was the influence of the highland Cushitic languages like Agew related to the failure of Emperor Libne Dingle and the raising of the Agwe. The reason why the pharyngeal sounds in the Tigrigna, Tigre, and Me'en languages are still not influenced is not known. Thus, the researcher rather believed that the Ge'ez pharyngeal $[\mathrm{h}]$ and $[0] /[\hbar],[\Gamma]$ could be influenced by Amharic language during the traditional teaching and learning process of the Ge'ez for liturgy services. The following words were taken from the purposely selected linguistic researches; in the words, the phonetic sounds including the target sounds are phonetically transcribed as follows.

\begin{tabular}{|c|c|c|}
\hline Ge'ez & Phonetic transcription & English \\
\hline ก) & [bIhlä] & said \\
\hline नीón & [bISlä] & became rich \\
\hline hขก & [kIhlä] & was able \\
\hline$h \times 4 h$ & [kwwh hlä] & put eye liner \\
\hline Pathin & [johannIs] & John \\
\hline$\theta d b_{0}$ & [s'əh hafle]. & Author \\
\hline 'מ9DA & [ hIməl] & load \\
\hline hLd & [haräsä] & ploughed \\
\hline TิUC. & [š́ahIr] & Ge'ez caladenr \\
\hline 909 & [maSs'o] & door \\
\hline Fo7d́ & [täSaggäsä] & he bide \\
\hline$\delta \omega_{1} C_{C}$ & [SIwwur] & blind \\
\hline $0,23 h$ & [SajnIkä] & eye of yours \\
\hline hข & [kIhlot] & ability \\
\hline$\dot{\partial \theta}$ & [SIs'] & herb \\
\hline$\lambda, \ell \hbar 90$ & [ PIjji?ammru] & they do not know \\
\hline híl & [ hasärä] & humiliated/disgraced \\
\hline 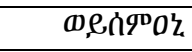 & [wä PIjjisämmfanni] & who he does not listen to me \\
\hline hhor & [?ahadu] & one/ the one \\
\hline$\varrho a v_{\theta} \hbar_{n}$ & [jImäs's'I?] & he will come \\
\hline hit & [ hanäs’ä] & he built/ constructed \\
\hline לकरू & [nəh has] & branz \\
\hline Cón & [rəSəS] & head \\
\hline nodit & [bəSalat] & holidays (special days) \\
\hline Pe & [hoj] & glory \\
\hline
\end{tabular}

Table 1

In all the above words, the Ge'ez symbols [ $h]$, and [o] are transcribed as the international pharyngeal sounds [h/

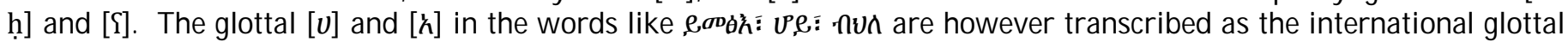
sounds [h], and [?]. In all the phonetic researches of the scholars the sounds including the pharyngeals have their own phonetic identity transcribed (pronounced) according to their historical feature. Faulty pronunciation of sounds can cause the decrement of the fidäls' since the future generation can write the words with even the glottal sounds. For example the word Ge'ez ( $\left.ๆ \hbar^{\prime} H\right)$ itself was written as $ๆ \dot{b}+$ in some books and that writing system had a parallel meaning with the verb "^શон [?agfazä] to mean "he derived" rather than the former which simply refers to "the name of the language".

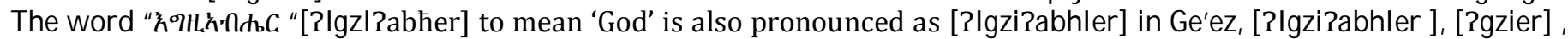
and [zihar], by Amharic speakers, and as [?Igzi?abhIer] , [?Izghar], and [?Izgiher] by Tigrigna speakers. Thus, the researcher argues that this can cause diminishing of the sounds value in the language or an interchangeable application of other sounds which are currently pronounced.

\subsection{Pictographic Analysis}

According to Gabriella page 6, one of the leading properties of the language is pictography. In the following diagram, she showed the ancient Egyptian hieroglyphics up to which some of the Ge'ez sounds were developed. 


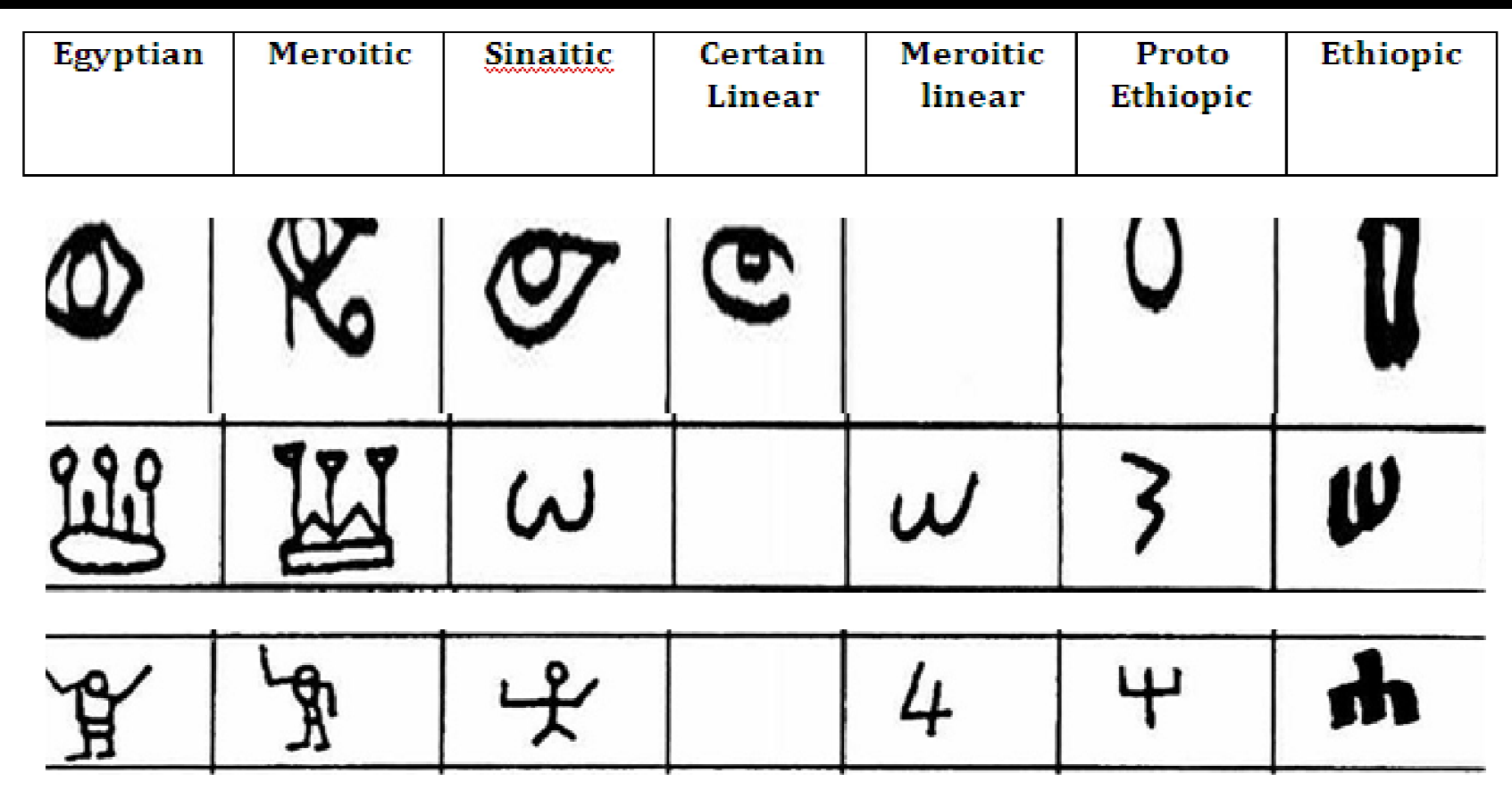

Figure 1

The Egyptian picture above to mean 'eye' is showing the actual image of an eye and the Ge'ez Pharyngeal " 0 " which is developed from it according to Gabriella is named after "oe'? 0 "[ [ajnu fa](the eye like ' $\mathrm{C}$ ') in Amharic for two reasons: First, it is used to write the Ge'ez word "o,e? / Yajn/"(eye) as an initial sound, second it is the pictograph of the image of an eye. Thus, this can assure the scholars' argument towards their conclusion that ge'ez was originated from

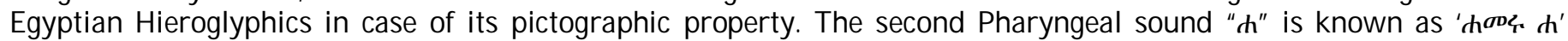

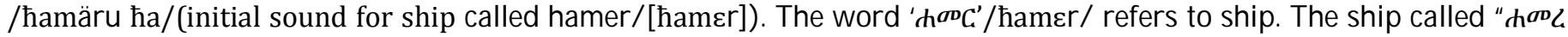
¡‘" [ћamärä nJ:h] was used by Noh to liberalize himself and his family from the hydraulic punishment of God in his village according to the Bible. Related to this, the Ge'ez sound ' $h$ '/ $\hbar$ / according to Nohamin W,(2008:7) refers to God's crucifixion for the sake of us. In the diagram, the ancient Egyptian pictography from which one of letters of $G e^{\prime} \mathrm{ez}$, ' $h$ ' $/ \hbar /$ was developed, looks like a person stretched his hands left and right which seems a person on cross.

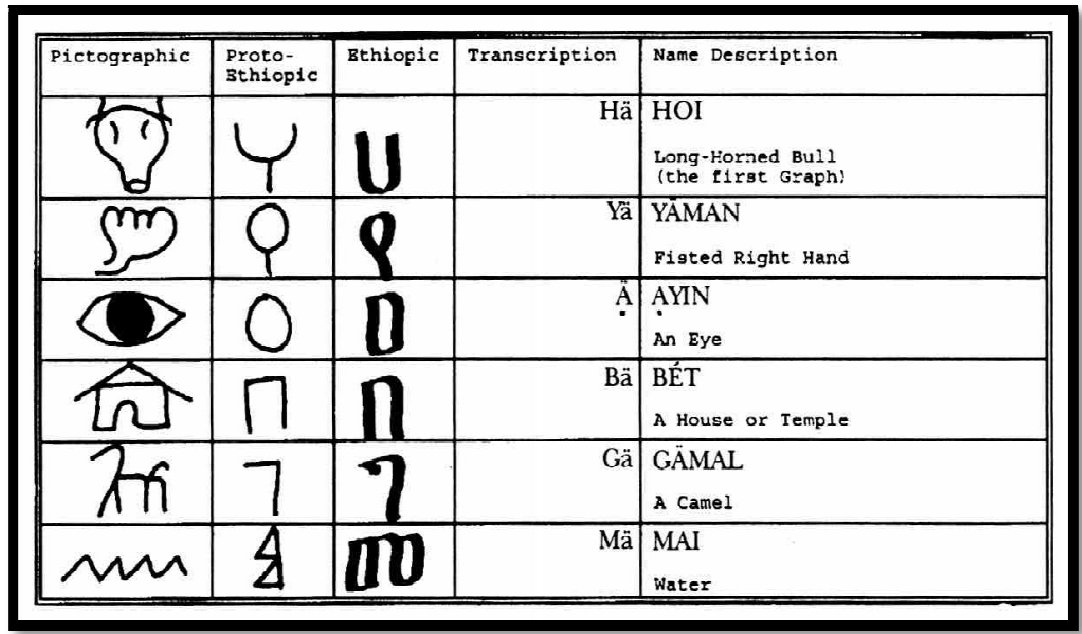

Figure 2

\subsection{Linguistic Analysis}

According to some linguists, Ge'ez is the language descended from Semitic language family which share common characteristics mainly in terms of the pharyngeal sounds. Laufen and Ladfogd sated above that the pharyngeal sounds are

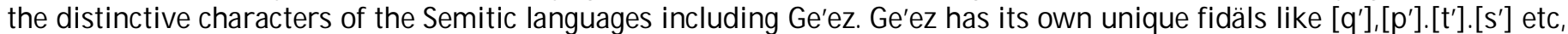
but the pharyngeals are the sounds that relate Ge'ez with its Semitic cognates like Arabic, Hebrew, Tigrigna, Tigre etc. The following words are the words constructed using either of the pharyngeal sounds which relate Ge'ez with the other sister Semitics. 


\subsubsection{Ge'ez, Arabic phonetic transcription, English}

\begin{tabular}{|c|c|c|c|}
\hline Ge'ez & Arabic & Phonetic transcription & English \\
\hline 0,03 & عين & [Sajn] & eye \\
\hline Pă̊: & 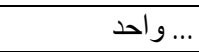 & [waћəd] & oneness/one \\
\hline dico & شرع | ماع & sär\{a]/Šärißa] & Ruled \\
\hline
\end{tabular}

Table 2

\subsubsection{Ge'ez (phonetic Transcription), tigrigna (phonetic transcription), English}

\begin{tabular}{|c|c|c|c|c|}
\hline Ge'ez & Phonetic transcription & Tigrigna & phonetic Transcription & English \\
\hline$\theta \phi, e$ & [ścћaj] & $\theta$ eh, $\mathrm{C}$ & [ ścћaj] & sun \\
\hline${ }^{h^{\sigma D}} \mathrm{C}$ & [ћamer] & $h^{\sigma D} C$ & [ћamer] & the ship \\
\hline $0 \mathbf{O}^{\mathbf{D}}$ & [Salcm] & $9 \lambda 9^{\mathrm{D}}$ & [Salcm] & glob \\
\hline dind & [sIbћat] & dinhth & [sIbћat] & compliment \\
\hline 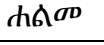 & [ halcme] & $h \Lambda^{\sigma o}$ & [haleme] & dream \\
\hline h.?.L & 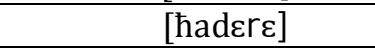 & h.S.L. & [ & lay over \\
\hline$\Lambda 90$ & [lämయä] & $\lambda 9 \mathbf{P} 0$ & [lämSä] & green \\
\hline$i n 0$ & [näbfä] & $4 \cdot n 0$ & [näbSä] & sorrow \\
\hline${ }^{a 0} \mathrm{OH}$ & [məケazä] & $\sigma 09 \mathrm{H}$ & [məSazä] & tasty \\
\hline$T d^{a v}$ & [ tə'sme] & $\mathrm{T}^{\mathrm{a}}, \boldsymbol{T}$ & [ tə'Samä] & delicious \\
\hline hho & [?ћadä] & 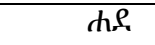 & [ћadä] & one \\
\hline$h \dot{\theta} L$ & [ћas’ärä] & $h \theta L$ & [ћas'ärä] & short \\
\hline$+07 w$ & [täSaggäsä] & $+07 w$ & [täYaggäsä] & bear with \\
\hline$\theta h, e$ & [s'əћај] & $\theta \pitchfork, e$ & [s'əћај ] & sun \\
\hline $0, Q_{a b}$ & [Saddämä] & $0, Q, a \mathrm{D}$ & [Saddämä] & invite \\
\hline 9,63 & [Sajn] & $9, \ell$. & [Sajni] & eye \\
\hline 9089 & [mass'o] & ${ }^{97} d 8$ & [mass'o] & door \\
\hline$\theta \mathrm{h} b$. & [s'əћafä ] & $\theta$ hb. & [s'cћaf] & write \\
\hline
\end{tabular}

Table 3

The above phonetically transcribed words are almost commonly found in the Semitic languages; all the words have similar meaning, but the orthographic system is either deferent from or modified of the other. Thus, that shows as the language is Semitic and is attributed with the pharyngeal sounds same as the others.

\section{Conclusion and Discussion}

Ge'ez is the ancient Ethiopian language which has its own syllabic writing system called Abugida. It was popular language up to the modern period. The traditional writing materials of Geez are: Brana, traditionally prepared inks, and feather of birds. This research is conducted in the phonetic aspect of the language specifically in the pharyngeal sounds. Ge'ez is enriched in letters/fidäls. The pharyngeal sounds and most attributes of the language are mispronounced as glottal these days. Many scholars wrote the proper image of these sounds in their researches. For instance, Marassinni $\mathrm{P}$

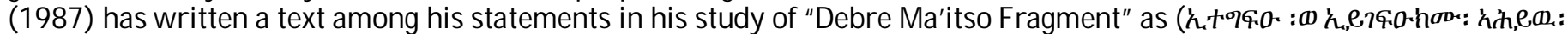
$\boldsymbol{\omega} \rho$ the Ge'ez pharyngeal $\langle\boldsymbol{h}\rangle$ as [h] unlike the IPA one; this is according to the philological convenience of the sound transcription, but the users of the language are sounding the pharyngeals as the glottal sounds. This is most probably because of the influence of Amharic language which doesn't have pharyngeals. Similarly, it is cited in Aethiopica (2010) as, scholars like Mekonn A. (1984), Enno L (1917), and Marcen C (1921), state that the traditional pronunciation of Geez consonants is heavily influenced by Amharic, and According to Ruhlen, M (1991), Semitic languages were diversifying in Ethiopia and Eretria, where, under heavy Cushitic influence, they split into a number of languages, including Amharic and Tigrigna. With the expansion of Ethiopia under the Selemonic Daynacity, Ge'ez remains the liturgical language for Christians in the country.

\section{Recommendations}

- The original sounds of the language must be preserved in all linguistic conformations.

- There should be an intervention in applying the finding of the research conducted in recognizing and pronouncing of the sounds for learners.

- A constructive study must be undergone on the actual origin of the Ge'ez letters.

- The institutions at which Ge'ez is launched as a department, should host researches through more. calls for the reason that the more research calls raise the more researchers Provoked to study the language will be.

- Reasons why some of the other Ge'ez fideäls are changed in the use of the language must be precisely studied.

- The sounds must be preserved in the current use of the language as they were before. 


\section{References}

i. Ayele B. 1997. An African writing system-its history and principles. Lawrenceville, Red sea Press.

ii. Baye Y. 1992. Ethiopian writing system. AAU. Addis Ababa Ethiopia.

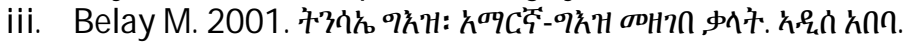

iv. Georges J. 1969. The story of Alphabets and Scripts. New York

v. Gabriella S. 1992. The Comparative Origin and Usage of the Ge'ez writing system of Ethiopia

vi. Laufen A. and Baer Th. 1988. The Emphatic and Pharyngeal Sounds in Hebrew and in Arabic. The Hebrew University, Jerusalem, Israel.

vii. Leslau W. 1957. The Phonetic treatment of the Arabic Loanwords in Ethiopic. Rutledge Taylor and Francis Group.

viii. _.1969. Frequency as Determinant of Linguistic Changes in the Ethiopian Languages. Published online (web source:http:/ / www.tandfonline.com/ action, (12 April 2017)

ix. Marassinni P. 1987. Linguistic oriental and Ethiopian studies in memory of paolo Marassinni. Merritt R. 1991. A Guide to the World's Languages: Classification

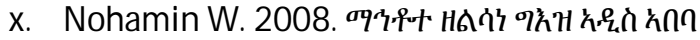

xi. Peter L. and Lan M. 1996. The sounds of the world's language. Oxford: Black well.

xii. Wninger S. 2010. Sounds of Ge'ez- ow to study the phonetics and phonology of an Ancient Language. Universitate Hamburg.

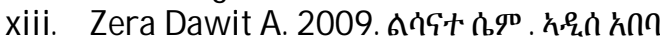

xiv. Web source: https:/ / en.m.wikipedia.org/wiki/ Ge'ez Ge'z skript 5 april 2017, 